\title{
Housing Capital-Gains Taxation and Homeowner Mobility: Evidence from the Taxpayer Relief Act of 1997
}

\author{
Christopher R. Cunningham* \\ Federal Reserve Bank of Atlanta \\ 1000 Peachtree Street \\ Atlanta, GA 30309 \\ Chris.Cunningham@atl.frb.org \\ Gary V. Engelhardt \\ Department of Economics and Center for Policy Research \\ Maxwell School of Citizenship and Public Affairs \\ 426 Eggers Hall \\ Syracuse University \\ Syracuse, NY 13210 \\ gvengelh@maxwell.syr.edu
}

January 3, 2007

\begin{abstract}
We provide new evidence on the impact of housing capital-gains taxation on homeowner behavior by examining residential mobility before and after the Taxpayer Relief Act of 1997 (TRA97), which generated the most sweeping reform of capitalgains taxation in the last two decades. In addition to lowering marginal tax rates on long-term capital gains for all assets, TRA97 also eliminated any differential treatment of housing gains above and below age 55, allowing all homeowners to qualify for capital-gains exclusions. Utilizing data drawn from the Current Population Survey (CPS) on either side of the law change (1996 and 1998) on homeowners just above (5658 year olds) and below (52-54 year olds) the age-55 threshold and a reduced-form, quasi-experimental empirical approach, our estimates suggest that the repeal of the differential capital-gains tax treatment by age embodied in TRA97 had an economically important and statistically significant impact on the residential mobility of under-55 homeowners. Across a variety of specifications, the repeal raised the mobility rate by around 1-1.4 percentage points, which, for a mean mobility rate of 4 percentage points, represented an increase in the mobility rate of homeowners in their early 50s by 22-31 percent. Furthermore, the bulk of this effect is concentrated among highly mobile homeowners who a priori were more likely to have wanted to trade down (e.g., divorced, empty nesters), those facing higher capital gains tax rates, and those living in states that had experienced higher rates of nominal appreciation.
\end{abstract}

* Corresponding author. The views of the paper are those of the authors and do not reflect the views of Syracuse University or the Federal Reserve Bank of Atlanta. 


\section{INTRODUCTION}

As has been long recognized in the urban and public economics literatures, the U.S. tax code subsidizes owner-occupied housing through the non-taxation of imputed rents, the deduction (for those who itemize) of mortgage-interest payments and property taxes, and the favorable treatment of capital gains. Prior to 1997, gains arising from the sale of a home were treated differently if the seller went on to buy a more (rather than a less) expensive home. In addition, preferential treatment was given based on age: homeowners age 55 or older qualified for a one-time exclusion of $\$ 125,000$ in calculating taxable gains, while younger homeowners did not qualify for this exclusion. Both of these provisions have led other researchers to conclude that, de facto, most gains for those over 55 went untaxed (Rosen, 1985; Burman, Wallace, and Weiner, 1996) and to consider the possibility that those under 55 who desired to trade down, buying a less expensive house, might have been effectively "locked-in" to their existing homes by the differential treatment according to age. This would result in a reduction in residential mobility, much as capital-gains taxes on appreciated stocks might reduce realizations, a topic of considerable interest in public and financial economics. ${ }^{1}$

However, there is only limited empirical evidence on the extent to which housing capital-gains taxation affects homeowner mobility in the United States. In particular, existing studies that have employed older cross-sectional household survey data (Hoyt and Rosenthal, 1990) may have had difficulty separately identifying the impact of the tax treatment from other, unobserved factors that generate cross-sectional

\footnotetext{
${ }^{1}$ See Blouin, Raedy, Shackelford (2000), Shackelford (2000), and Sinai and Gyourko (2004), among others for recent research.
} 
differences in outcomes. At the same time, studies that used panel data exploited now distant legislative changes, primarily from the 1970s (Newman and Reschovsky, 1987; Sinai, 1998).

In this paper, we provide new evidence of the impact of housing capital-gains taxation on mobility by examining homeowner behavior before and after the Taxpayer Relief Act of 1997 (TRA97), which generated the most sweeping reform of capitalgains taxation in the last two decades. In addition to lowering marginal tax rates on long-term capital gains for all assets, TRA97 also eliminated any differential treatment of housing gains above and below age 55, allowing all homeowners to qualify for capital-gains exclusions. We utilize data drawn from the Current Population Survey (CPS) on either side of the law change (1996 and 1998) on homeowners just above (5658 year olds) and below (52-54 year olds) the age-55 threshold in a reduced-form, quasi-experimental approach to estimate the impact of the repeal of the age-55 rule on the relative mobility of these two groups of homeowners.

Overall, the empirical evidence we present suggests that the repeal of the agespecific capital-gains tax treatment embodied in TRA97 had an economically important and statistically significant impact on the residential mobility of under-55 homeowners. Across a variety of specifications, the repeal raised the mobility rate by around 1-1.4 percentage points, which, for a mean mobility rate of 4 percentage points, implies that TRA97 raised the mobility rate of homeowners in their early 50s by 22-31\%. Furthermore, the bulk of this effect is concentrated among highly mobile homeowners who a priori were more likely to have wanted to trade down (e.g., divorced, empty nesters), those facing higher capital gains tax rates, and those living in states that had 
experienced higher rates of nominal appreciation. Interestingly, these findings are generally consistent in magnitude with the estimates of Newman Reschovsky (1987) and Sinai (1998), who relied on more modest reforms in the 1970s and early 1980s. In combination, these three studies suggest that capital-gains taxation of owner-occupied housing prior to 1997 likely resulted in substantial housing lock-in effects.

The paper is organized as follows. Section II gives background on the tax treatment of housing capital gains before and after the Taxpayer Relief Act of 1997 and a brief review of key existing studies of gains taxation on housing behavior. Section III describes the regression framework, CPS, and the construction of the analysis dataset. Section IV discusses the estimation results. There is a brief conclusion.

\section{BACKGROUND}

A capital gain for tax purposes on the primary residence is calculated as the difference between the sale price net of transactions cost and the adjusted tax basis, the latter of which is the purchase price plus the value of tax-qualified improvements. Prior to TRA97, a homeowner was expected to postpone paying capital-gains tax on a sale if the subsequent home, purchased within two years, was of equal or greater value. Postponed gains were subtracted from the tax basis in the new home. This had the effect of increasing the taxable gain on the new home, should it ever be sold. For example, if an owner sold a home for $\$ 200,000$ that had been purchased for $\$ 150,000$, with no improvements, and bought a new home for $\$ 225,000$, the adjusted tax basis in the new home would be $\$ 175,000$ (i.e., $\$ 225,000-\$ 50,000=\$ 175,000$ ), so that effectively the $\$ 50,000$ gain in the previous home was transferred to the new home, deferring the tax. Alternatively, if the homeowner traded down, buying a less 
expensive home, then the difference between the sale price of the previous home and the purchase price of the new home was treated as a taxable gain and taxed in the year of sale. ${ }^{2}$ Adapting the example above, suppose the seller instead bought a new home for $\$ 185,000$. The immediate taxable gain would have been $\$ 15,000(\$ 200,000$ $\$ 185,000=\$ 15,000)$ and the balance of the gain deducted from the basis in the new home $(\$ 185,000-\$ 35,000=\$ 150,000){ }^{3} \quad$ Long-term capital-gains were taxed at two rates, $15 \%$ and $28 \%$, for households in the $15 \%$ and $28 \%$ (and higher) ordinary income tax brackets, respectively. ${ }^{4}$ Therefore, there was an asymmetry in the way gains were taxed: deferral if trading up, immediate taxation if trading down.

Prior to 1997, there also was a special provision for homeowners who were 55 or older, who, when trading down, could utilize a one-time lifetime exclusion up to $\$ 125,000$ in gains. $^{5}$ For this age group, sales with gains greater than the exclusion would trigger tax only on the excess. For example, if a 56 year-old homeowner in 1996 down-sized, and the home had an associated $\$ 150,000$ taxable gain, the $\$ 125,000$ exclusion would have reduced the taxable capital gain to just $\$ 25,000$ (i.e., $\$ 150,000$ $\$ 125,000=\$ 25,000)$. A 54 year-old homeowner in a similar position would not have been entitled to an exclusion. Therefore, prior to 1997, the federal tax law gave

\footnotetext{
${ }^{2}$ A home seller who moved into rental housing and did not buy a new home within two years paid tax on the entire gain.

${ }^{3}$ Note that if a homeowner does not contribute additional equity by buying a more expensive house, the new home simply takes on the smaller of the basis of the previous home or the new home purchase price.

${ }^{4}$ With TRA86, the top statutory ordinary income tax bracket was $28 \%$, but was raised by Congress twice in the early 1990s, so that, by 1996, the first year in our sample below, there were three additional brackets, with rates of $31 \%, 36 \%$, and $39.6 \%$, respectively. The short-term gains' rate applies to assets held for less than 12 months. In 1996, short-term gains were taxed at the ordinary rate, but the rate on long-term gains was capped at $28 \%$, conferring preferential treatment to long-term gains for households in these higher brackets.

${ }^{5}$ This exclusion was the same for married couples and single persons. The Economic Recovery Tax Act of 1981 raised the exclusion to $\$ 125,000$.
} 
preferential capital-gains tax treatment to homeowners 55 and older relative to younger homeowners. ${ }^{6}$ Throughout the analysis, we refer to this provision as the age-55 rule.

TRA97 made four important changes. First, it eliminated the age-55 rule and, therefore, any differential treatment of homeowners based on age. Second, it eliminated the one-time lifetime exclusion of $\$ 125,000$ and replaced it with a new exclusion of $\$ 500,000$ in gains for a married couple ( $\$ 250,000$ for a single person) that applies not once in a lifetime, but to each home sold after May 6, 1997. ${ }^{7}$ Third, it eliminated the deferral of taxes; all gains above the new exclusions are now taxed in the year of sale. Finally, it lowered the long-term capital-gains rates from $15 \%$ and $28 \%$ to $10 \%$ and $20 \%$, respectively. ${ }^{8}$

Overall, before TRA97, the taxation of gains was asymmetric, depending upon trading up versus trading down and whether the owner was above or below age 55 . This differential treatment was eliminated with the tax reform. This generates two testable empirical predictions. First, there should have been less trading down in the market by under-55 homeowners before 1997 than after, because trading down was penalized before but not after the reform. Second, due to the penalty on trade-downs, homeowners under 55 before the law change should have been less mobile, as those households desiring cheaper housing may have chosen to remain in their existing home

\footnotetext{
${ }^{6}$ Sellers 55 or older trading down with less than $\$ 125,000$ in taxable gains could not utilize the balance of the exclusion on a subsequent sale.

${ }^{7}$ The residency requirement to use the new exclusion also was relaxed. After TRA97 sellers only needed to live in the home for two of the last five years. The previous rule was three of five years. Home sellers had a three-month window after May 6, in which they could choose to be taxed under the old provisions. The law did not provide for indexation of the new exclusions, so that their real value has been falling over time.

${ }^{8}$ Specifically, TRA97 reduced the long-term gains rate on assets held 18 months or more. This holding period subsequently was reduced to 12 months by the Internal Revenue Service Restructuring and Reform Act of 1998 (IRSRRA98).
} 
and avoid the tax. Moreover, this reduced mobility should have been differential according to the marginal capital-gains tax faced.

In the empirical analysis, we use the variation in incentives induced by the enactment of TRA97 and quasi-experimental methods to compare the mobility of 5254 year-old homeowners-just under the age-55 cut-off-to that of 56-58 year-old homeowners_-just over the age-55 cutoff_-before (1996) versus after (1998) the law change to test the second of these predictions. In addition, we exploit the fact that mobility is concentrated among certain demographic groups even in the absence of the law change, and then see if these high-mobility groups were differentially affected by TRA97 to help provide evidence that our findings are robust. As a further robustness check, we stratify the sample by rates of house price appreciation and tax rates to see whether households with larger potential tax liabilities also had the largest relative lock-in effect.

Our use of legislative variation in capital-gains tax rules to attempt to identify the impact on mobility is similar to two previous studies. With data from the $1970-81$ Panel Study of Income Dynamics (PSID), Newman and Reschovsky (1987) exploited pre- versus post-1978 values of the exclusion and the age threshold to estimate the impact of capital-gains taxation on homeowner mobility. Specifically, prior to 1978, the one-time lifetime exclusion was $\$ 20,000$ from $1964-75, \$ 35,000$ in 1976-77, $\$ 100,000$ from 1978-80, $\$ 125,000$ after 1980. The exclusion was limited to those 65 and over before 1978 and to those 55 and over after the law change. Their multinomial logit estimates indicated that these changes in housing capital-gains taxation increased the likelihood of moving by 0.7 percentage points, which represented a $23 \%$ increase in 
the mobility rate for an average homeowner between ages 55 and 64. Similarly, Sinai (1998) exploited the legislative changes in the treatment of the housing capital-gains base in 1976, 1978 and 1986, the age threshold in 1978, and the size of the one-time exclusion in 1978 and 1981 to estimate a competing-risks hazard model of trading up, trading down, or transition to renting for homeowners in the PSID. ${ }^{9}$ He found that an increase in the capital-gains tax liability lowered the likelihood of trading down or renting, but not of trading up. In summary, both studies found evidence consistent with the presence of a substantial lock-in effect.

\section{III.REGRESSION FRAMEWORK, DATA, AND IDENTIFICATION}

The data for our analysis come from the March CPS, which has a number of advantages for examining homeowner mobility. First, it is a standard data source for the study of demography and migration. Second, each March survey is a large, crosssectional, nationally representative sample of households, which yields large analysis datasets, even for relatively narrow age ranges. Third, the March interview asks whether the household moved to a new house over the last year. We use this question to generate our one-year residential mobility rate in an initial difference-in-difference analysis and as our binomial dependent variable in the linear probability model presented at the end of this section. Finally, the Housing Vacancy Survey, which is the

\footnotetext{
${ }^{9}$ Before 1988, only 40 percent of long-term gains were included in taxable income and the tax rate on such gains was capped at $25 \%$, so that capital gains enjoyed preferential tax treatment relative to ordinary income. As a result of the Tax Reform Act of 1986 (TRA86), this preference was eliminated, and, beginning in 1988 the entirety of the gain was subject to tax and at the same maximum rate as income.
} 
official government source for homeownership rates, is a derivative of the CPS, so that the CPS is a natural survey data source to study. ${ }^{10}$

We use a relatively narrow range of ages on either side of 55 (52-54 and 56-58 year olds) for three reasons. First, as one goes younger in the age distribution, it is more likely that homeowners will want to trade-up for life-cycle reasons, not trade down, and the age-55 rule was only binding for those under 55 who wanted to trade down. Second, as one goes older in the age distribution, retirement and work decisions at older ages begin to drive housing-mobility decisions. The mid- to late-1990s were a period of rapid change in the retirement landscape for workers in their 60 's, with a rise in labor force participation after a very long period of secular decline, changes in the Social Security retirement-earnings test, and increased penetration of defined contribution pension plans. We do not want these changes to confound our estimates. Finally, the key identifying assumption is that in the absence of the repeal of the age-55 rule, the mobility rates of homeowners around age 55 would not otherwise have differed across time. The larger the age range around 55, the less likely this assumption holds.

The questions in the CPS are about income earned in the previous calendar year, so that the income data in the March 1997 and 1999 CPS refer to 1996 and 1998, respectively. Likewise, the mobility questions refer to moves since the previous March. Therefore, data drawn from the March 1997 CPS refer to behavior before the law change and data drawn from the March 1999 CPS refer to behavior after the law

\footnotetext{
${ }^{10}$ Unfortunately, the CPS does not ask any questions on the value of homes or improvements with which to more finely measure gains, basis, and whether moves resulted in trading-up or trading-down, so that we are not able to test all of the empirical implications of TRA97 for homeowners. We discuss this in greater detail in the conclusion.
} 
change. Because the law was signed in August, 1997 but applied retroactively to home sales in May 1997, we do not use information for 1997 (i.e., from the March 1998, CPS).

Table 1 gives selected descriptive statistics. Pooled across both years, there are 7,159 observations on homeowners aged 52-54 and 56-58 in the analysis dataset. The sample mean residential mobility rate is $4.4 \%$, which indicates that only a small fraction of homeowners move in a given year. Interestingly, this is similar to what Newman and Reschovsky (1987) found for homeowners in the 1970s in their analysis of the PSID.

As a point of departure, we begin with the most basic form of analysis from the quasi-experimental literature: a simple difference-in-difference estimate of the impact of the age-55 rule on homeowner mobility, illustrated in Table 2. The focal group consists of 52-54 year old homeowners, shown in the first row, who were subject to the age-55 rule before, but not after, 1997. The comparison group consists of 56-58 year old homeowners, shown in the second row, who were not subject to the age-55 rule. We refrain from using the more familiar terms of "treatment” and "control” groups, because all homeowners' capital-gains taxation changed with the law, and, hence, technically, all were "treated" by the law change, although to differing degrees. In particular, the difference-in-difference analysis exploits this differential treatment and measures the relative difference in mobility generated by repeal of the age-55 rule. ${ }^{11}$

\footnotetext{
11 We do not view renters as an appropriate control group for homeowners. At this stage in the lifecycle-mid-50s-renters and owners are very different and, hence, not comparable, groups in terms of socio-economic status and geographic mobility. In addition, the mobility of renters in this period is confounded by, among other factors, expansions of the Earned Income Tax Credit, changes in the labormarket returns to low-skilled workers, the enactment of the major federal welfare reform (PWRORA) in 1996 and phased in during the late 1990s (Meyer and Rosenbaum, 2001; Autor and Duggan, 2003).
} 
Each cell in the table contains the mobility rate, the percent of homeowners who moved in the past year. For example, in column 1, 4.27\% of 52-54 year old homeowners moved in 1996, the pre-reform period. Standard errors are shown in parentheses. Compared to 56-58 year olds, whose mobility rate was $4.6 \%$ in the prereform period, 52-54 year olds had a 0.46 percentage point lower mobility rate in this period, shown as the group difference in the third row of column 1 . However, after the law change, the same calculation for the post-reform period indicates that 52-54 year olds had a 0.53 percentage point higher mobility rate in 1998. Therefore, taking the difference in these group differences, 52-54 year-old homeowners before the repeal of the age-55 rule had a 0.99 percentage point lower mobility rate relative to $56-58$ year olds. With a standard error of 0.46 , this is significantly different than zero at all standard cut-offs. Relative to the mobility rate of 52-54 year olds in 1996, this estimate implies that the repeal raised the homeowner mobility rate by $23.2 \%$ (i.e., $0.99 / 4.27=0.232)$.

While the simple analysis in Table 2 suggests that TRA97 had important effects on homeowner mobility, it has an important limitation in that it did not take into account other factors that may have affected mobility and been correlated with the repeal. To control for these, we expand the analysis into a regression framework. Specifically, we begin with the following specification:

$$
M_{i t}=\boldsymbol{\delta}^{\prime} \mathbf{X}_{i t}+\boldsymbol{\alpha} \mathbf{Z}_{i t}^{\text {Age }}+\gamma D_{i t}^{\text {pre-TRA97 }}+\beta D_{i t}^{\text {under } 55} \times D_{i t}^{\text {pre-TRA97 }}+u_{i t},
$$

where $i$ and $t$ index the household and calendar year, respectively, $M$ denotes a dummy variable that is one if the homeowner moved in the last year and zero otherwise, $D^{\text {under55 }}$ is a dummy for whether the homeowner is under $55, D^{\text {pre-TRA97 }}$ is a 
dummy for whether the homeowner is observed before the law change, $\mathbf{Z}$ is a vector of age dummies by single year of age of the household head, $u$ is a disturbance term, and the term $\mathbf{X}$ is a vector of additional covariates intended to control for other influences on homeowner mobility that may have varied across age or time between 1996 and 1998.

The parameter $\beta$ indicates the differential response in mobility for 52-54 year old homeowners relative to 56-58 year old homeowners before compared with after the law change. It measures this response in a more general way than the simple difference-in-difference analysis in Table 2 by including a full set of age effects $(\mathbf{Z})$ and conditioning on other influences ( $\mathbf{X})$. After controlling for age and time effects, the estimate of $\beta, \hat{\beta}$, is identified off of age-by-time, or year-of-birth, variation. In particular, the identifying assumption is that there were no other factors affecting the relative mobility of 52-54 years old homeowners over time, other than through the law change. If capital-gains taxation locked under-55 homeowners in, then $\beta<0$. Likewise, the relative impact of the repeal of the age- 55 rule is measured as $-\beta$.

\section{ESTIMATION RESULTS}

The first two columns of Table 3 present ordinary least squares (OLS) estimation results from the linear probability model in (1). The first row of the table shows the estimate of $\beta$ multiplied by 100 to express mobility effects in terms of percentages, rather than decimals, for ease of exposition. ${ }^{12}$ Heteroscedasticity-robust standard errors clustered by year of birth are shown in parentheses.

\footnotetext{
${ }^{12}$ The estimates for the full set of parameters for all specifications are available upon request from the authors.
} 
In column 1 , all covariates $(\mathbf{X})$ are excluded, so that $\hat{\beta}$ is a regression-based simple difference-in-difference estimate, but, in contrast to Table 2, it lets baseline mobility rates differ by single year of age. This estimate is $\hat{\beta}=-0.97$, which indicates that 52-54 year old homeowners had 0.97 percentage points lower mobility than 56-58 year olds homeowners before versus after the law change. Based on the standard error of 0.45 , this effect is statistically significant. Compared to the sample mean mobility rate of 4.43 percentage points, a reduction of 0.97 represents a $21.9 \%$ reduction in the mobility rate (i.e., $-0.219=-0.97 / 4.43$ ). These effects are similar in magnitude to those estimated by Newman and Reschovsky (1987) from the 1970s reforms.

One way in which all homeowners were "treated” by TRA97 was the adoption of the new exclusions of $\$ 500,000$ and $\$ 250,000$ for married couples and single individuals, respectively, discussed above, which changed incentives for homeowners in a manner that varied across time and marital status. To account for this in the estimation, in column 2, we include in $\mathbf{X}$ a dummy variable for married and an interaction of that dummy and the year dummy. Controlling for the adoption of the new exclusions does not appreciably change the estimate of $\beta .^{13}$

One possible challenge to our initial findings is that the capital-gains changes in TRA97 changed the mix of households that were homeowners, and that this change was correlated with mobility but not related to lock-in per se. For example, by creating additional tax subsidies for owner-occupied housing, TRA97 may have drawn marginal

\footnotetext{
${ }^{13}$ The estimated marginal effects from probit maximum likelihood estimation of $\beta$ in columns 1 and 2 are -0.00919 and -0.00921 , respectively. Similarly, the estimated marginal effects from complementary log-log maximum likelihood estimation, which performs better than probit with outcomes that occur relatively rarely, such as mobility, were -0.00919 and -0.00936 , respectively, which indicates robustness across estimators.
} 
renters into homeownership, and because changing tenure largely necessitates moving, this could have driven the increase in mobility for 52-54 year olds associated with the reform. To test whether TRA97 actually drew marginal renters into homeownership, we estimated the models in columns 1 and 2, with the outcome variable being a dummy for homeownership, in effect determining whether homeownership rates were changing in the same direction as homeowner mobility. These results are presented in columns 3 and 4 , respectively. The parameter estimate is not statistically different from zero at standard levels of significance and the economic magnitude of the estimate is very small, which suggests that 52-54 year old households just before the law were no more (or less) likely to be homeowners. The results in column 4 show that this finding also holds when we control for being married before and after TRA97.

Table 4 illustrates the robustness of the baseline estimation results for homeowner mobility when additional covariates are added to $\mathbf{X}$ in (1). In column 1 , we include a full set of dummy variables for marital status (married, divorced or separated, widowed), number of children under age 19, education (high school diploma, some college, college or advanced degree), race (white) and sex (female). In addition, these variables are interacted with the year 1998 dummy and thus allowed to have a differential impact on mobility over time. Now, $\hat{\beta}=-1.19$ is statistically different from zero at the 0.7 percent level, and implies a lock-in effect of $26.9 \%$. Column 2 allows the impact of the demographic and education variables on mobility to vary by single year of age. The estimate of $\beta$ is essentially unchanged.

Columns 3 and 4 include measures of real after-tax total family income as covariates. Total income refers to the sum of money income from all sources received 
by family members during the calendar year. ${ }^{14}$ Total taxes paid are defined as annual federal and state income and payroll taxes and, following Engelhardt, Gruber, and Perry (2005) and Engelhardt (2006), are calculated for each family based on demographic characteristics and the sources and amounts of income received by family members using the NBER's TAXSIM Calculator. ${ }^{15}$ For homeowners who moved, state taxes were calculated for the state of residence prior to the move, so that the net income measure would not be endogenous by construction. The CPS does not have enough information on tax deductions to allow for a calculation of itemized deductions, so all tax-filing units were assumed to claim the standard deduction. After-tax family income is gross family income less family taxes paid. All income measures were deflated into real 2001 dollars using the all-items Consumer Price Index (CPI) and then adjusted by the Organization on Economic Cooperation and Development (OECD) equivalence scale for each family's size to measure real net income per adult equivalent. In column 3, this income measure is entered in $\mathbf{X}$ as a quartic; in column 4, this quartic is interacted with the age and year dummy variables, respectively, to allow income to affect mobility in a very flexible functional form. The addition of these income terms has little effect on the estimate of $\beta$.

In column 5, we add to the specification two measures that affect housing decisions - the user-cost measure of Green and Vandell (1999), which, following Engelhardt (2006), incorporates federal and state tax rates calculated from NBER's TAXSIM calculator for each family, and the real value of the standard deduction for each household's filing status, which may drive a wedge between the marginal and

14 The CPS asks questions about money income only. There is no information to quantify the incomeequivalent in-kind transfers received. 
average cost of homeownership. ${ }^{16}$ We also include a full set of state dummies and state-by-year interactions to account for location-specific trends in mobility that just might happen to have been correlated with the law change. Now, $\hat{\beta}=-1.36$ is statistically different than zero at the 2.2 percent level, and implies a lock-in effect relative to households over 55 of $30.7 \%$.

As a final check on robustness, we estimate the richest specification from column 5 of Table 4 on alternative sets of years. These results are shown in Table 5 . First, an additional feature of TRA97 was that it changed the holding period to qualify for long-term gains treatment on all assets, including housing, from 12 to 18 months. A year later, as part of a separate law, the Internal Revenue Service Restructuring and Reform Act of 1998 (IRSRRA98), the holding period was changed back to 12 months. In addition, in 1999, both houses of Congress signed the Tax Reform and Reconciliation Act of 1999 (TRRA99), which further lowered the long-term tax rates from $20 \%$ and $10 \%$ to $18 \%$ and $8 \%$, respectively, but President Clinton ultimately vetoed the bill later that year. To make sure the holding period change due to IRSRRA98 and the proposed rate changes in TRRA99 did not somehow contaminate the analysis thus far, which relied on 1998 as the "after" period, we re-estimate the specification using 1996 as the "before" and 2000 as the "after" periods, respectively. These results are shown in column 1 , where $\hat{\beta}=-0.96$. They are qualitatively similar to what was found in Tables 3 and 4 and implies an increase in relative mobility of $22 \%$ from the repeal of the age-55 rule.

\footnotetext{
${ }^{15}$ A description of this program is provided in Feenberg and Coutts (1993).

${ }^{16}$ Again, for homeowners who moved, state refers to the state of residence prior to the move.
} 
Second, the estimates in Tables 2-4 only employ one year of data after the reform, 1998, and, hence, measure a short-term response to the law. To help gauge whether, in the medium-term, in which households had a longer time to adjust their desired housing consumption (Sinai, 1998), the law had an impact on mobility, we estimate the specification using multiple "after" years, in particular, 1998-2000 and 1998-2002. The results employing these longer after periods are shown in columns 2 and 3 of Table 5, respectively. Again, the estimates and implied economic effects are qualitatively similar to those in the previous tables, with increases in the mobility rate of about $23 \%$ for $52-54$ year-old relative to $56-58$ year-old homeowners, suggesting important medium-term impacts. ${ }^{17}$

\section{Estimates for High-Mobility Demographic Groups}

If the relative changes in mobility documented in Tables 2-4 are plausibly due to TRA97, then we should expect to see different patterns of response for high versus low mobility homeowners, especially those who otherwise might desire to trade down. To explore this, we estimate the richest specification from column 5 of Table 4 separately for four demographic groups that have been documented to have high mobility rates-the divorced and widowed, empty-nesters, college-educated, and

\footnotetext{
${ }^{17}$ One common robustness check in quasi-experimental analyses is a regression using data from multiple years only from the "before" period to check for pre-existing differential trends, often called a "pseudodifference-in-difference" estimate. In 1994, the CPS moved to a computer-assisted personal interview (CAPI) format, updated its sampling frame based on the 1990 Census, introduced a new questionnaire, and instituted a number of other changes to the survey. Pitkin (1998) and Masnick, McArdle, and Belsky (1999) have analyzed the effect of these changes on measured trends in aggregate homeownership in the 1990s using the CPS. They found that, concurrent with these changes, there appears to be an unusually large increase in the number of households and the homeownership rate as measured in the CPS between 1994 and 1996, and that measured changes in homeownership and mobility before versus after 1994 in the CPS may have been spurious. This prevents us from performing a pseudo-difference-in-difference regression for the current study.
} 
white-as well as their complements, the results of which are summarized in Table 6 . For example, column 1 shows the results when the model is estimated on the subsample of divorced and widowed homeowners, who are highly mobile (Engelhardt, 2003), may be more likely to be mismatched in their housing consumption and want to trade down (Hanushek and Quigley, 1979), and, therefore, should have responded more to the law change than their complement, married and never married homeowners, shown in column 2. Indeed, this turns out to be the case: $\hat{\beta}=-4.80$ for the divorced and widowed, is statistically different from zero at the 0.06 percent level, and implies a relative increase in mobility of $89.5 \%$, i.e., almost a doubling, from the repeal of the age-55 rule. In contrast, there is essentially no change in relative mobility for married and never married homeowners: the estimate of $\beta$ is economically much smaller, and we cannot reject the null hypothesis that the relative mobility of 52-54 year-old married and never married homeowners was unaffected by the tax change.

In columns 3 and 4 , we look at households with and without children. Homeowners whose children have left home may be consuming more housing than they desire and are looking to downsize, while families with children in the home are still in their child-rearing phase and may be substantially less likely to trade down. Consistent with this prediction, the parameter estimate on households with children (column, 4) is half the size for empty-nesters (column 3) and not statistically different from zero.

In the remainder of the table, columns 5 and 6 show a qualitatively similar pattern for those with a college degree or more in education versus those with less than a college degree, respectively. However, the response to TRA97 did not seem to vary 
by race. Overall, the results in Table 6 show an empirical pattern that is consistent with TRA97 having had an important effect on homeowner mobility.

\section{Estimates Based on Capital-Gains Tax Rates and Nominal Appreciation}

As another check that the relative changes in mobility documented in Tables 2-4 are plausibly due to TRA97, we next examine whether mobility is responsive to higher capital-gains tax liability. First, we use NBER's TAXSIM Calculator to calculate the first-dollar marginal long-term capital-gains tax rate the homeowner would face, based on family income, demographics, and the prevailing tax law. We then divide the sample into those who would pay at $15 \%$ rate and those who would pay at the $28 \%$ rate and estimate the richest specification from column 5 of Table 4 separately. These results are summarized in columns 1 and 2 of Table 7, respectively.

In particular, we would expect that 52-54 year old homeowners in the $28 \%$ bracket would have responded more to the elimination of the age-55 rule than those in the $15 \%$ bracket because, for any given gain, they faced a larger potential tax liability than those in the 15\% bracket. Qualitatively speaking, the results are not inconsistent with this. Namely, in column $1, \hat{\beta}=-2.02$ and is statistically different than zero at the 0.26 percent level implying a relative increase in mobility of $46.1 \%$ from the repeal of the age-55 rule for those in the $28 \%$ bracket. In comparison, in column $2, \hat{\beta}=-1.49$, is not statistically different than zero, and implies a smaller relative increase in mobility of $33.3 \%$ for those in the $28 \%$ bracket. However, the point estimates are sufficiently close and the estimation imprecise enough that there is substantial overlap in the $95 \%$ 
confidence intervals for these estimates, so that the between-group differences are not as stark as, say, those between marital groups documented in Table 6 .

In another approach, we use the OFHEO constant-quality repeat-sales price indices from each state to calculate the nominal appreciation rate each homeowner would have faced if the home had been occupied for 16 years, which was the median length of residence for 52-58 year-old homeowners in the 1990 Census IPUMS. ${ }^{18}$ We then divide the sample into two equal-sized groups, those who lived in states that experienced nominal appreciation above versus below the median nominal appreciation rate in the sample, respectively, and then estimate the richest specification from column 5 of Table 4 separately for these groups. These results are summarized in columns 3 and 4 of Table 7, respectively.

In particular, we would expect that 52-54 year old homeowners in high appreciation-rate states, who faced a larger potential liability than those in low appreciation-rate states, would have responded more to the elimination of the age-55 rule (than those in the low appreciation-rate states). The results are consistent with this hypothesis. In column $3, \hat{\beta}=-2.44$ and is statistically different from zero at the 3.65 percent level. This implies a relative increase in mobility of 56.0\% among those in high appreciation-rate states as a result of the repeal of the age-55 rule. In comparison, in column $2, \hat{\beta}=0.07$ and is not statistically different than zero, implying a relative decrease in mobility of $1.6 \%$ for those in low appreciation-rate states. Therefore, all of

\footnotetext{
${ }^{18}$ The CPS does not ask homeowners the length of time in residence in the home. The CPS also does not ask at what age the household first purchased a home and even if did, Burman, Wallace, and Weiner (1996) find that only half of all home sellers filed the requisite IRS form 2119 suggesting that households may not be tracking basis across homes. For these reasons, we focus on the expected length of ownership of the current house and not on the sum of lifetime gains.
} 
the relative mobility effect is concentrated among under-55 homeowners in states that experienced high rates of nominal appreciation in the 1980s and early-1990s.

Because the tax treatment of capital gains is related to the dollar amount of the nominal gain, and not to the rate of nominal appreciation per se, columns 5 and 6 present a similar analysis in which the sample was split based on the median nominal gain expressed in dollars. These gains were calculated for each state from the OFHEO nominal appreciation rates used in columns 3 and 4, anchored by the median house value for 52-58 year-old homeowners in each state calculated from the 1990 Census IPUMS. The results in columns 5 and 6 show a similar pattern: the relative mobility effect is concentrated among under-55 homeowners in states that experienced high dollar amounts of nominal capital gains.

Finally, Table 8 combines the separate analyses of tax rates and nominal appreciation in Table 7 to see if the relative mobility response by age was concentrated among homeowners who a priori would have been expected to have faced the largest tax liabilities if they wanted to trade down: high- (versus low-) tax rate homeowners within the high-appreciation states. Specifically, we split the sample into four groupshigh tax-rate, high appreciation; high tax-rate, low appreciation; low tax-rate, high appreciation; and low tax-rate, low appreciation—and estimate the model separately for each group, the results of which are shown in columns 1-4, respectively. Panel A of the table shows the estimates of $\beta$ when the appreciation measure is the nominal appreciation rate; panel B shows the estimates when this measure is the dollar amount of the nominal gain. 
The results are mixed. Using the appreciation rate (panel A), the bulk of the relative mobility response by age is concentrated among high tax-rate homeowners in high appreciation-rate states, compared to the other groups. These results are consistent with households distorting their mobility in minimize their tax liability. However, using the imputed dollar amount of the nominal gains (panel B), the relative mobility response by age continues to be concentrated among homeowners in high gain states, consistent with the results in Table 5, but does not appear to differ by tax rate, as anticipated.

\section{CONCLUSION}

In summary, the weight of the empirical evidence suggests that the repeal of the differential capital-gains tax treatment by age embodied in TRA97-the so-called age55 rule-had an economically important and statistically significant impact on the mobility of under-55 homeowners. Across a variety of specifications, the repeal raised the mobility rate by $22-31 \%$, with the bulk of this effect concentrated among highly mobile homeowners who a priori were more likely to have wanted to trade down (e.g., divorced, empty nesters), those facing higher capital gains tax liabilities. These findings are generally consistent with and extend the conclusions of Newman Reschovsky (1987) and Sinai (1998) that relied on early and more modest reforms in the tax treatment of capital gains from housing.

There are two important caveats. First, while this article presents evidence for the presence of an age-55 lock-in effect by showing a change in relative homeowner mobility before versus after 1997, our estimates technically do not represent the causal impact (in an absolute sense) of gains taxation on mobility because all homeowners 
were "treated" by the law change. Second, even though the repeal of the age-55 rule induced an increase in the mobility rate of homeowners in their early 50 s by $22-31 \%$, the flow of these "new" movers is very small relative to the stock of all homeowners, simply because only about 4 percent of homeowners in their 50s move in any given year. This suggests that TRA97 probably did not have a large aggregate impact on housing-market activity.

The principal limitation of the study is its inability to directly observe tradedowns. Because the CPS provides little information about housing, we do not know if increased post-reform mobility of households 52-54 was generated by people moving to less valuable homes. Instead, our analysis is predicated on the assumption that some portion of the population would like to own less housing and that a subset of that group delayed their trading down move to avoid or minimize their tax liability. While the findings presented here are strongly consistent with this hypothesis, we will complement this paper with future research examining housing consumption, tenure and migration utilizing the Health and Retirement Study (HRS), a nationally representative longitudinal survey of American households aged 50 and older from 1992 to the present. The HRS contains a rich set of demographic, household composition, income and employment questions that will allow us to track changes in housing demand over time and, thus, predict the degree of mismatch between current and desired levels of housing consumption. This will also allow us to assess the extent to which the repeal of the age- 55 rule freed suburban homeowners to move to less expensive central city locations, as in Bier, Maric and Weizer (2000). 


\section{REFERENCES}

Autor D, and M Duggan 2003. The Rise in the Disability Rolls and the Decline in Unemployment. Quarterly Journal of Economics 118:157-205.

Bier, T, I Maric, and W Weizer 2000. A Preliminary Assessment of the New Home Seller Capital Gains Law. Housing Policy Debate 11:645-73.

Blouin, JL, JS Raedy, and DA Shackelford 2000. “Capital Gains Holding Periods and Equity Trading: Evidence from the 1998 Act,” NBER Working Paper No. 7827.

Burman, LE, S Wallace, and D Weiner 1996. How Capital Gains Taxes Distort Homeowners' Decisions. In Proceedings of the Eighty-Ninth Annual Conference on Taxation held under the auspices of the National Tax Association. Boston, Massachusetts: National Tax Association.

Engelhardt, GV 2003. Nominal Loss Aversion, Housing Equity Constraints, and Household Mobility: Evidence from the United States. Journal of Urban Economics 53: 171-195.

Engelhardt, GV 2006. Social Security and Elderly Homeownership. Mimeo, Syracuse University.

Engelhardt, GV, J Gruber, CD Perry, 2005. Social Security and Elderly Living Arrangements: Evidence from the Social Security Notch. Journal of Human Resources 40: 354-372.

Feenberg, D and E Coutts, 1993. An Introduction to the TAXSIM Model. Journal of Policy Analysis and Management 12:1

Hanushek, EA, and JM Quigley 1979. The Dynamics of the Housing Market: A Stock Adjustment Model of Housing Consumption. Journal of Urban Economics 6:90-111.

Hoyt, WH, and SS Rosenthal 1990. Capital Gains Taxation and the Demand for Owner-Occupied Housing. Review of Economics and Statistics 72:45-54

Masnick, GS., N McArdle, and ES Belsky 1999. A Critical Look at Rising Homeownership Rates in the United States Since 1994. Harvard University Joint Center for Housing Studies Paper No. W99-2.

Meyer, B, and D Rosenbaum 2001. Welfare, The Earned Income Tax Credit, and the Labor Supply of Single Mothers. Quarterly Journal of Economics 116:10631114. 
Newman, S, and J Reschovsky 1987. An Evaluation of the One-Time Capital Gains Exclusion for Older Homeowners. American Real Estate and Urban Economics Association Journal 15:704-24.

Pitkin, JR 1998. Changes in Homeownership and Households, 1993 to 1995: An Evaluation of Estimates from the Current Population Survey. Journal of Housing Research 9: 317-326.

Rosen, H, 1985. Housing Subsidies. AJ Auerbach and M Feldstein Handbook of Public Economics, Volume 1 (Amsterdam: North Holland), pp. 375-420.

Sinai, T, 1998. Taxation, User Cost, and Household Mobility Decisions. Wharton School Working Paper \#303, University of Pennsylvania.

Sinai, T, and J Gyourko, 2004. The Asset Price Incidence of Capital Gains Taxes: Evidence from the Taxpayer Relief Act of 1997 and Publicly Traded Firms. Journal of Public Economics 88:7-8-1543-1565.

Shackelford, DA, 2000. Stock Market Reaction to Capital Gains Tax Changes: Empirical Evidence from the 1997 and 1998 Tax Acts. James M. Poterba, ed., Tax Policy and the Economy, Volume 14 (Cambridge, MA: MIT Press), pp. 6792. 
Table 1. Sample Means for Selected Variables, Standard Deviations in Parentheses

\begin{tabular}{|c|c|c|c|c|c|}
\hline & $\begin{array}{c}\text { Household } \\
\text { Head Age } 52 \\
\text { to } 54 \text { and } 56 \\
\text { to } 58,1996- \\
1998\end{array}$ & $\begin{array}{l}\text { Household } \\
\text { Head Age } 52 \\
\text { to } 54,1996\end{array}$ & $\begin{array}{l}\text { Household } \\
\text { Head Age } \\
52 \text { to 54, } 1998\end{array}$ & $\begin{array}{l}\text { Household } \\
\text { Head Age } 56 \\
\text { to 58, } 1996\end{array}$ & $\begin{array}{c}\text { Household } \\
\text { Head Age } \\
56 \text { to 58, } \\
1998\end{array}$ \\
\hline Moved & 0.044 & 0.043 & 0.0462 & 0.047 & 0.041 \\
\hline Age & $\begin{array}{l}55.149 \\
(2.758)\end{array}$ & $\begin{array}{c}53.294 \\
(2.032)\end{array}$ & $\begin{array}{c}53.199 \\
(1.855)\end{array}$ & $\begin{array}{l}57.357 \\
(1.813)\end{array}$ & $\begin{array}{l}57.341 \\
(1.659)\end{array}$ \\
\hline Married & 0.730 & 0.735 & 0.735 & 0.731 & 0.706 \\
\hline Divorced/Separated & 0.178 & 0.181 & 0.183 & 0.161 & 0.185 \\
\hline Widowed & 0.048 & 0.038 & 0.035 & 0.058 & 0.066 \\
\hline Never married & 0.046 & 0.046 & 0.047 & 0.049 & 0.043 \\
\hline High school drop out & 0.125 & 0.115 & 0.099 & 0.159 & 0.133 \\
\hline High school grad & 0.323 & 0.324 & 0.288 & 0.357 & 0.329 \\
\hline Some college & 0.252 & 0.250 & 0.282 & 0.218 & 0.251 \\
\hline College grad & 0.160 & 0.168 & 0.183 & 0.141 & 0.142 \\
\hline More than college & 0.140 & 0.142 & 0.147 & 0.125 & 0.144 \\
\hline White & 0.898 & 0.900 & 0.895 & 0.888 & 0.909 \\
\hline Female & 0.342 & 0.317 & 0.340 & 0.349 & 0.367 \\
\hline $\begin{array}{l}\text { Real family-size } \\
\text { Adjusted net income } \\
\text { (OECD) in thousands }\end{array}$ & $\begin{array}{c}30.001 \\
(25.383)\end{array}$ & $\begin{array}{c}29.067 \\
(23.732)\end{array}$ & $\begin{array}{c}30.801 \\
(25.057)\end{array}$ & $\begin{array}{c}28.449 \\
(25.729)\end{array}$ & $\begin{array}{c}31.456 \\
(26.972)\end{array}$ \\
\hline User Cost & $\begin{array}{c}0.132 \\
(0.007)\end{array}$ & $\begin{array}{c}0.127 \\
(0.006)\end{array}$ & $\begin{array}{c}0.138 \\
(.004)\end{array}$ & $\begin{array}{c}0.127 \\
(0.004) \\
\end{array}$ & $\begin{array}{c}0.137 \\
(0.003)\end{array}$ \\
\hline Observations & 7,159 & 1,847 & 1,990 & 1,563 & 1,759 \\
\hline
\end{tabular}


Table 2. Difference-in-Difference Estimates of the Relative Impact of the Age-55 Rule on the Homeowner Mobility Rate, Standard Errors in Parentheses

\begin{tabular}{|c|c|c|c|}
\hline & (1) & (2) & (3) \\
\hline Group/year & $\begin{array}{c}\text { Pre-TRA97 } \\
(1996)\end{array}$ & $\begin{array}{c}\text { Post-TRA97 } \\
(1998)\end{array}$ & $\begin{array}{l}\text { Time difference } \\
\text { for groups }\end{array}$ \\
\hline Ages 52-54 & $\begin{array}{l}4.27 \\
(0.23)\end{array}$ & $\begin{array}{c}4.62 \\
(0.52)\end{array}$ & $\begin{array}{l}-0.35 \\
(0.43)\end{array}$ \\
\hline Ages 56-58 & $\begin{array}{c}4.73 \\
(0.09)\end{array}$ & $\begin{array}{l}4.09 \\
(0.18)\end{array}$ & $\begin{array}{c}0.64 \\
(0.14)\end{array}$ \\
\hline $\begin{array}{l}\text { Group difference at } \\
\text { a point in time: }\end{array}$ & $\begin{array}{l}-0.46 \\
(0.23)\end{array}$ & $\begin{array}{c}0.53 \\
(0.49)\end{array}$ & \\
\hline Difference-in-Difference: & & & $\begin{array}{l}-0.99 \\
(0.46)\end{array}$ \\
\hline \multicolumn{4}{|c|}{$\begin{array}{l}\text { Note: Each cell gives the one-year mobility rate of homeowners expressed in } \\
\text { percentage points for each of the age groups, as described in the text. The time } \\
\text { difference for groups is defined as pre-reform minus post-reform. The group } \\
\text { difference at a point in time is defined as ages } 52-54 \text { minus ages } 56-58 \text {. Standard } \\
\text { errors, clustered by year of birth, are in parentheses. }\end{array}$} \\
\hline
\end{tabular}


Table 3. Linear Probability Model Estimates of Mobility and Homeownership, Standard Errors in Parentheses

\begin{tabular}{|c|c|c|c|c|}
\hline \multirow[t]{2}{*}{ Dependent Variable: } & \multicolumn{2}{|c|}{ Moved } & \multicolumn{2}{|c|}{ Homeowner } \\
\hline & (1) & (2) & (3) & (4) \\
\hline $\begin{array}{l}\text { Dummy if under age } \\
55 \times \text { Pre-TRA97 }\end{array}$ & $\begin{array}{l}-0.97 \\
(0.45)\end{array}$ & $\begin{array}{l}-0.98 \\
(0.44)\end{array}$ & $\begin{array}{c}0.32 \\
(0.95)\end{array}$ & $\begin{array}{c}1.06 \\
(0.81)\end{array}$ \\
\hline Sample mean & 4.43 & 4.43 & 82.61 & 82.61 \\
\hline Percent change & $-21.9 \%$ & $-22.1 \%$ & $0.4 \%$ & $1.2 \%$ \\
\hline Dummy if married & - & $\begin{array}{l}-0.78 \\
(0.82)\end{array}$ & - & $\begin{array}{c}24.42 \\
(01.48)\end{array}$ \\
\hline $\begin{array}{l}\text { Dummy if married } \\
\times \text { Pre-TRA97 }\end{array}$ & - & $\begin{array}{c}0.07 \\
(0.99)\end{array}$ & - & $\begin{array}{l}-3.64 \\
(2.31)\end{array}$ \\
\hline Year fixed effects & Yes & Yes & Yes & Yes \\
\hline Age fixed effects & Yes & Yes & Yes & Yes \\
\hline $\begin{array}{l}\text { Year fixed effects } \\
\times \text { Married }\end{array}$ & No & Yes & No & Yes \\
\hline $\mathrm{R}^{2}$ & .0003 & .0005 & .0026 & 0817 \\
\hline Observations & 7159 & 7159 & 8666 & 8666 \\
\hline \multicolumn{5}{|c|}{$\begin{array}{l}\text { Note: Columns (1) and (2) present the difference in difference estimates from a linear } \\
\text { probability model with dummy variables for year and age and with and without interacted } \\
\text { married effects. Columns (3) and (4) present estimates from regress homeownership status } \\
\text { on the same set of variables. Standard errors, clustered by year of birth, are in parentheses. }\end{array}$} \\
\hline
\end{tabular}


Table 4. Linear Probability Model Estimates of Mobility with Additional Covariates and Interactions, Standard Errors in Parentheses

\section{(1)}

(2)

(3)

(4)

(5)

User-cost, Real

Include Fully Interact

Demographic Demographic and Education Variables with Age

Net Income Variables

\section{Fully Interact} Income with Age and Year
Value of Standard

Deduction, State

Effects Interacted with Year
Dummy if under age
$55 \times$ Pre-TRA97

Sample mean

Percent change

Year fixed effects

$\times$ Marital status

$\times$ Number of kids

$\times$ Educational attainment

$\times$ Race

$\times$ Sex

$x$ Income

$\times$ State dummies

Age fixed effects

$\times$ Marital status

$\times$ Number of kids

$\times$ Educational attainment

$\times$ Race

$\times$ Sex

$x$ Income

State Fixed Effects

Real net income (OECD)

entered as a quartic

User-cost

Real value of standard

deduction

$\mathrm{R}^{2}$
(0.33)

4.43

$-26.9 \%$

No

Yes

No

No

No

No

No

No

No

No

No

No

0.0045

7159

\section{$-1.17$}

(0.36)

4.43

$-26.4 \%$

Yes

Yes

Yes

Yes

Yes

Yes

No

No

$-1.25$

(0.34)

4.43

$-28.2 \%$

Yes

Yes

Yes

Yes

Yes

Yes

No

No

Yes

Yes

Yes

Yes

Yes

Yes

No

No

No

No

No

0.0122

7159
$-1.21$

(0.39)

4.43

$-27.3 \%$

Yes

Yes

Yes

Yes

Yes

Yes

Yes

No

Yes

Yes

Yes

Yes

Yes

Yes

Yes

No

Yes

No

No
$-1.36$

(0.47)

4.43

$-30.7 \%$

Yes

Yes

Yes

Yes

Yes

Yes

Yes

Yes

Yes

Yes

Yes

Yes

Yes

Yes

Yes

Yes

Yes

Yes

Yes

Note: Marital status includes married, divorced/separated, widowed and omits single. Education attainment consists of high school, some college, college grad, more than college, and omits less than high school. Race is a dummy variable for white. Income is a quartic specification of family size-adjusted (OECD) real net income. User cost is the after-tax cost of housing. Standard errors, clustered by year of birth, are in parentheses. 
Table 5. Linear Probability Model Estimates of Mobility with Different Years, Standard Errors in Parentheses

\begin{tabular}{|c|c|c|c|}
\hline & $\begin{array}{c}(1) \\
\text { Years: 1996, } \\
2000\end{array}$ & $\begin{array}{c}(2) \\
\text { Years: 1996, } \\
\text { 1997-2000 }\end{array}$ & $\begin{array}{c}(3) \\
\text { Years: 1996, } \\
\text { 1997-2002 }\end{array}$ \\
\hline $\begin{array}{l}\text { Dummy if under age } \\
55 \times \text { Pre-TRA97 }\end{array}$ & $\begin{array}{l}-0.96 \\
(0.55)\end{array}$ & $\begin{array}{l}-1.02 \\
(0.46)\end{array}$ & $\begin{array}{l}-1.01 \\
(0.27)\end{array}$ \\
\hline Sample mean & 4.39 & 4.53 & 4.44 \\
\hline Percent change & $-21.9 \%$ & $-22.5 \%$ & $-22.8 \%$ \\
\hline $\begin{array}{l}\mathrm{R}^{2} \\
\text { Observations }\end{array}$ & $\begin{array}{c}0.0335 \\
7500\end{array}$ & $\begin{array}{l}0.0259 \\
15,221\end{array}$ & $\begin{array}{l}0.0225 \\
27,568\end{array}$ \\
\hline \multicolumn{4}{|c|}{$\begin{array}{l}\text { Note: All specifications include controls for marital status, number of } \\
\text { resident children, educational attainment, race, sex, income, user cost, value } \\
\text { of standard deduction, and state dummies interacted with dummy variables } \\
\text { for age and year. Standard errors, clustered by year of birth, are in } \\
\text { parentheses. }\end{array}$} \\
\hline
\end{tabular}


Table 6. Linear Probability Model Estimates of Mobility by Demographic Groups, Standard Errors in Parentheses

\begin{tabular}{|c|c|c|c|c|c|c|c|c|}
\hline & (1) & (2) & (3) & (4) & (5) & (6) & (7) & (8) \\
\hline & $\begin{array}{l}\text { Divorced, } \\
\text { Separated, } \\
\text { Widowed }\end{array}$ & $\begin{array}{c}\text { Married, } \\
\text { Never } \\
\text { Married }\end{array}$ & $\begin{array}{l}\text { Households } \\
\text { without } \\
\text { Children } \\
\text { less than } 19\end{array}$ & $\begin{array}{l}\text { Households } \\
\text { with } \\
\text { Children less } \\
\text { than } 19\end{array}$ & $\begin{array}{c}\text { College } \\
\text { Degree or } \\
\text { Higher }\end{array}$ & $\begin{array}{l}\text { Less } \\
\text { than } \\
\text { College } \\
\text { Degree }\end{array}$ & White & Non-white \\
\hline $\begin{array}{l}\text { Dummy if under age } \\
55 \times \text { Pre-TRA97 }\end{array}$ & $\begin{array}{l}-4.80 \\
(0.88)\end{array}$ & $\begin{array}{l}-0.64 \\
(0.61)\end{array}$ & $\begin{array}{l}-1.08 \\
(0.39)\end{array}$ & $\begin{array}{l}-0.61 \\
(1.95)\end{array}$ & $\begin{array}{l}-2.13 \\
(0.79)\end{array}$ & $\begin{array}{l}-1.48 \\
(0.65)\end{array}$ & $\begin{array}{l}-1.23 \\
(0.38)\end{array}$ & $\begin{array}{l}-1.61 \\
(3.69)\end{array}$ \\
\hline Sample mean & 5.36 & 4.15 & 4.31 & 4.95 & 4.61 & 4.35 & 4.38 & 4.81 \\
\hline Percent change & $-89.5 \%$ & $-15.4 \%$ & $-25.1 \%$ & $-12.3 \%$ & $-46.0 \%$ & $-34.0 \%$ & $-28.1 \%$ & $-33.3 \%$ \\
\hline $\begin{array}{l}\mathrm{R}^{2} \\
\text { Observations }\end{array}$ & $\begin{array}{c}0.1099 \\
1623 \\
\end{array}$ & $\begin{array}{c}0.0401 \\
5536 \\
\end{array}$ & $\begin{array}{c}0.0354 \\
5827 \\
\end{array}$ & $\begin{array}{c}0.1676 \\
1332 \\
\end{array}$ & $\begin{array}{c}0.0884 \\
2149 \\
\end{array}$ & $\begin{array}{c}0.0457 \\
5010 \\
\end{array}$ & $\begin{array}{c}0.0349 \\
6432 \\
\end{array}$ & $\begin{array}{c}0.2378 \\
727 \\
\end{array}$ \\
\hline
\end{tabular}

Note: All specifications include controls for marital status, number of resident children, educational attainment, race, sex, income and state dummies interacted with age and year. Standard errors, clustered by year of birth, are in parentheses. 
Table 7. Linear Probability Model Estimates of Mobility for Households in States with High and Low Nominal Capital Gains and in High and Low Income Tax Brackets, Standard Errors in Parentheses
(1)
(2)
(3)
(4)

(5)

(6)

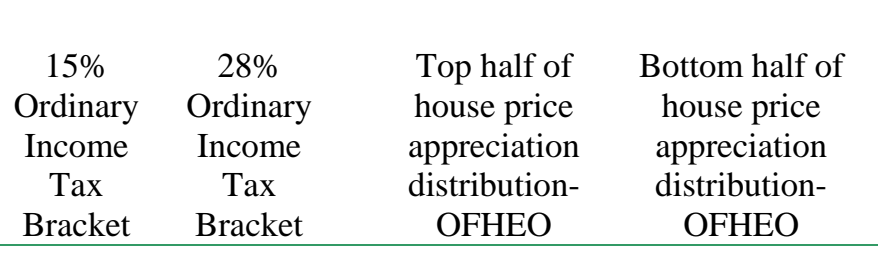

Top half of
house price
appreciation
distribution-
imputed
nominal gain

Bottom half of house price appreciation distributionimputed nominal gain
$-1.49 \quad-2.02$

(1.02)

(0.47)

4.48

4.38

$-33.3 \%$

$-46.1 \%$

0.0703

3484

3675
$-2.44$

(0.97)

4.36

$-56.0 \%$

0.0408

3604

$$
0.07
$$

(0.48)

4.50

$1.6 \%$

0.0538

3555
0.67

(1.15)

4.42

$15.1 \%$

Observations

Note: All specifications include controls for marital status, number of resident children, educational attainment, race, sex, income, user cost, value of standard deduction, and state dummies interacted with dummy variables for age and year. Columns (3) and (4) were selected based on rate of appreciation in the state OFHEO index between 1996 or 1998 and 1980. Columns (5) and (6) were selected based on the imputed nominal dollar gain of the median priced home from the 1990 census indexed by the state OFHEO series. Standard errors, clustered by year of birth, are in parentheses. 
Table 8. Linear Probability Model Estimates of Mobility for Homeowners in States with High and Low Nominal Capital Gains in High and Low Income Tax Brackets, Respectively, Standard Errors in Parentheses

(1)

(2)

Top Half of

Distribution for house price appreciation, 28\%

Income Tax Bracket or Higher
Top Half of Nominal Gains

Distribution and

15\% Income Tax
(3)

(4)
Dummy if under age

$55 \times$ Pre-TRA97

Sample mean

Percent change

$\mathrm{R}^{2}$

Observations

Dummy if under age

$55 \times$ Pre-TRA97

Sample mean

Percent change

$\mathrm{R}^{2}$

Observations

A. Gains based on rate of appreciation in OFHEO index

$-3.03$

(0.94)

4.92

$-61.6 \%$

0.0717

1992
$-1.49$

(1.74)

3.66

$-40.1 \%$

0.0994

1612
Bottom Half of

Distribution for house price appreciation, 28\%

Income Tax Bracket or Higher
Bottom Half of Nominal Gains Distribution and 15\% Income Tax Bracket

Note: All specifications include controls for marital status, number of resident children, educational attainment, race, sex, income, user cost, value of standard deduction, and state dummies interacted with dummy variables for age and year. Parameter estimates in panel A are from observations selected in part based on the rate of appreciation in the state OFHEO index between 1996 or 1998 and 1980. Parameter estimates in Panel B are from observation selected based on the imputed nominal dollar gain of the median priced home from the 1990 census indexed by the state OFHEO series. Standard errors, clustered by year of birth, are in parentheses. 